\title{
Effects of anthropogenic stress on the presence of parasites in a threatened population of black howler monkeys (Alouatta pigra)
}

\author{
Rodolfo Martínez-Mota ${ }^{1 *}$, Gilberto Pozo-Montuy², Yadira M. Bonilla Sánchez², and Thomas R. Gillespie ${ }^{3}$ \\ ${ }^{1}$ Department of Biology, University of Utah. 257S 1400E, Salt Lake City, 84112. Utah, United States. Email: rmarti39@illinois.edu (RMM). \\ ${ }^{2}$ Dirección de Investigación y Vinculación Académica, Conservación de la Biodiversidad del Usumacinta A. C. Gregorio Méndez 56, \\ Colonia Centro, CP. 86990, Emiliano Zapata. Tabasco, México. Email: gilpozo@cobius.org (GPM); bonillamagali@yahoo.com.mx (YMBS). \\ ${ }^{3}$ Departments of Environmental Sciences and Rollins School of Public Health, Emory University. 201 Dowman Drive, Atlanta, \\ 30322. Georgia, United States. Email: thomas.gillespie@emory.edu (TRG). \\ * Corresponding author
}

Habitat disturbance disrupts the ecological interactions of mammals, leading to negative consequences for biodiversity. In particular, it is suggested that parasite-host interactions are affected in tropical ecosystems, with parasite diversity reduced as environmental perturbations take place. In this study, we examined whether the disruption of tropical forests affects the presence of parasites in a population of endangered black howler monkeys (Alouatta pigra) that inhabits a highly fragmented landscape in Balancán, Tabasco, Mexico. Our working hypothesis was that increased forest perturbation would negatively affect the incidence of parasitic infections (parasite presence and richness) in black howler monkeys. We conducted a parasitological study and collected stool samples from 65 adult individuals living in 30 forest fragments across a disturbance gradient. We recovered parasite eggs from stool samples using flotation and sedimentation techniques. We selected fragment size and distance from each forest fragment to the nearest village as measures of forest perturbation. We analyzed the effects of forest perturbation on parasite presence and richness using generalized linear models. Other driving factors such as seasonality, host density, and sex were also considered in the models. Gastrointestinal parasite infection was positively related to distance between forest fragments and the nearest human settlement $(\beta=0.55 \pm S E 0.28, z=2.0, P=0.05$ ). No effects of fragment size or any other variable considered in the model on the presence of parasite infection were observed. Parasite richness was not affected by any of the measures of forest perturbation, nor by any other variables considered in the analysis. Our findings suggest that an increase in forest perturbation may negatively affect the probability of parasite infection in black howler monkeys, as individuals living in close proximity to human settlements showed a lower presence of parasites. We proposed that the low parasite infection rates recorded in this monkey population reflect synergistic effects associated with both the alteration of the parasiteprimate network, as well as the low resilience of parasites to thrive in a disrupted ecosystem.

Los disturbios de hábitat alteran las interacciones ecológicas de los mamíferos con consecuencias negativas para la biodiversidad. En particular, se ha observado que en los ecosistemas tropicales las interacciones entre parásitos y primates son afectadas, y la riqueza de parásitos es reducida conforme aumenta el grado de perturbación ambiental. En este estudio exploramos los efectos de la presión antrópica sobre la presencia y riqueza de parásitos gastrointestinales de una población de monos aulladores negros (Alouatta pigra) que habitan un paisaje altamente fragmentado en Balancán, Tabasco, México. Predecimos que un incremento en la perturbación del bosque afectará negativamente medidas de infección parasitaria (presencia y riqueza de parásitos) en monos aulladores negros. Llevamos a cabo un estudio coproparasitológico y colectamos muestras fecales de 65 individuos adultos que habitan 30 fragmentos de bosque a lo largo de un gradiente de perturbación. A través de técnicas de concentración por flotación y sedimentación recuperamos huevos de parásitos. Seleccionamos el tamaño de los fragmentos habitados por monos y la distancia que existe entre un fragmento y el poblado más próximo como medidas de perturbación del bosque. Analizamos los efectos de la perturbación del bosque sobre medidas de infección parasitaria usando modelos lineales generalizados. Otras variables como la estacionalidad, la densidad de hospederos y el sexo de individuos también fueron consideradas en los modelos. Encontramos que la distancia entre un fragmento de bosque y el poblado más cercano predice positivamente la presencia de infección parasitaria $(\beta=0.55 \pm E E 0.28, z=2.0$, $P=0.05$ ). Ninguna otra variable tuvo efectos significativos sobre la presencia de parásitos. Las medidas de perturbación del bosque y otras variables consideradas no tuvieron efectos significativos sobre la riqueza de parásitos. Nuestros resultados indican que la presencia de parásitos gastrointestinales disminuye en hospederos que habitan fragmentos que se encuentran en cercanía a asentamientos humanos, lo cual sugiere que un incremento en el grado de perturbación del bosque reduce el parasitismo en monos aulladores negros. Proponemos que las bajas tasas de parasitismo observadas en esta población de monos aulladores reflejan una sinergia derivada de la reducción en la conectividad entre parásitos y hospederos, y de la poca resiliencia de los parásitos para sobrevivir en un ecosistema altamente transformado.

Key words: Habitat perturbation; Mexico; parasites; primates; species loss; tropical forest.

(c) 2018 Asociación Mexicana de Mastozoología, www.mastozoologiamexicana.org

\section{Introduction}

Human activities such as agriculture and extensive cattle ranching, extraction of fossil fuels, overexploitation of resources and urbanization have all significantly impacted ecosystems worldwide (Hosonuma et al. 2012). Anthropic impact has affected the diversity and abundance of species, endangering the survival of their populations (Haddad et al.
2015; Ribeiro et al. 2015). In fact, organizations such as the International Union for the Conservation of Nature, as well as various authors, recognize that the accelerated loss of species and drastic ecosystem alterations have set off a global biodiversity crisis (IUCN 2017; Johnson et al. 2017). Conservation efforts and strategies to understand and/or reverse extinction trends generally focus on species that are either 
appealing or of interest to man (Donaldson et al. 2016). However, extinction processes associated with organisms perceived as harmful or associated with a negative condition, such as parasites, are poorly documented (Strona 2015).

Ecosystem disturbance (e. g., deforestation), defined by Rykiel (1985) as the set of processes that cause environmental disturbance (e. g., fragmentation and loss of habitat), disrupt ecological interactions at various levels, for instance, by changing food webs and mutualistic interactions (Morris 2010). The documented ecological changes between organisms involving several mammals species have shown that the host-parasite dynamics is one of the aspects affected in disturbed systems (e. g., marsupials, Puttker et al. 2008; rodents, Bordes et al. 2015). For example, it has been found that in colonization processes, transmission rates and the maintenance of parasitic infections decrease in hosts whose populations have been fragmented and isolated (Bush et al. 2013; Bordes et al. 2015). Therefore, a prevalent hypothesis in parasite ecology theory is that the diversity and abundance of parasites decrease as environmental disruption increases (Lafferty and Kuris 2005; Lafferty 2012).

The loss of parasite diversity may be aggravated in populations of hosts that are threatened to some extent (Farrell et al. 2015). Conwell et al. (2012) suggest that organisms such as parasites may undergo co-extinction along with their hosts, since the transmission of parasites is harder to sustain in isolated populations with low host density. In support of this hypothesis, Altizer et al. (2007) found in a meta-analysis that several species of threatened primates have a lower richness of parasite species versus unthreatened populations. The order Primates represents an excellent model to explore the effects of habitat disturbance on parasitism patterns in endangered hosts, since over $60 \%$ of the species of primates are under some category of threat (Estrada et al. 2017), and most are habitat specialists. Therefore, assessing parasitic infection patterns in endangered primates provides valuable information for the conservation of hosts and their ecological interactions.

The black howler monkey (Alouatta pigra) is a Neotropical primate currently threatened of extinction due to habitat loss and the conversion with tropical forests into farming land (Estrada 2015; IUCN 2017). This species is endemic to Mesoamerica (Mexico, Guatemala and Belize) and $80 \%$ of its distribution range is estimated to be located in southeastern Mexico in the states of Tabasco, Campeche, Quintana Roo, and northern Chiapas (Estrada 2015). The municipality of Balancán, Tabasco, is home to one of the populations of black howler monkey most severely affected by changes of land use (Pozo-Montuy et al. 2011). Between 1960 and 1975, the federal government promoted colonization programs coupled with extensive livestock raising and agriculture, which resulted in the loss of 115,000 hectares of forest and the conversion of both rainforests and the so-called tintales (vegetation dominated by Haematoxylum campechianum) into pastures and cropland (Isaac-Márquez et al. 2008). This municipality currently includes fragments of the original vegetation of different sizes not covered by government protection (Pozo-Montuy et al. 2008); for this reason, the populations of howler monkeys in this region have been proposed as a priority for preserving the species (Pozo-Montuy et al. 2008; Tobón et al. 2012). A parasitological investigation of this population may illustrate how habitat disturbance has affected ecological interactions between wild primates and other organisms.

The objective of this study was to document the effects of habitat disturbance on parasitism in black howler monkeys (A. pigra) inhabiting a landscape that has been highly impacted by human activities in the municipality of Balancán, Tabasco, Mexico. As habitat disruption affects the host-parasite interactions, we expected that increased levels of rainforest disturbance would reduce the presence and richness of $\mathrm{Gl}$ parasites in the black howler monkey. Also, since parasitic infections may follow seasonal patterns and are affected by demographic and intrinsic aspects of hosts (2006), this study also considered seasonality as well as ecological density and sex of individual hosts as potential predictors of parasite presence and richness.

\section{Materials and Methods}

Study Area. The study was carried out in a fragmented landscape in the municipality of Balancán, Tabasco, Mexico ( $17^{\circ}$ $40^{\prime} \mathrm{N},-91^{\circ} 30^{\prime} \mathrm{W}$; Figure 1). The remnants of vegetation (i.e., fragments of howler monkey habitat, sensu Pozo-Montuy et al. 2013) in this area are located within a matrix of habitats that include livestock pasture, forestry plantations (cedar, Cedrela odorata; teak, Tectona grandis; melina, Gmelina arborea; and eucalyptus, Eucalyptus sp.), and cropland (e. g., sorghum, rice, maize). These fragments are scattered in an area of 21,900 hectares bordered by the Usumacinta river and various water bodies (Pozo-Montuy et al. 2008). The original vegetation in this area has been described as low and medium subdeciduous forest and tinto low thorny tropical forest (H. campechianum; López-Mendoza 1980;

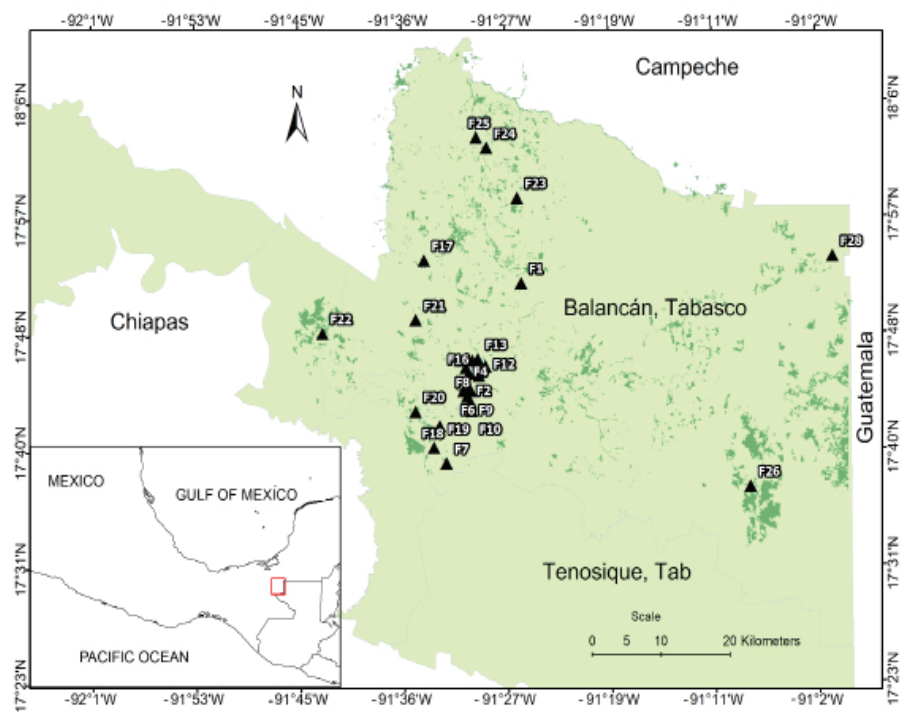

Figure 1. Fragmented landscape in the municipality of Balancán, Tabasco, Mexico. The image shows fragments of remnant forest in the study area, including the fragments sampled and human settlements. 
Pozo-Montuy et al. 2011). Annual precipitation is $1,976 \mathrm{~mm}$ and mean annual temperature is $27.9^{\circ} \mathrm{C}$ (CNA 2017).

Sample Collection. As part of a long-term research (2005 - 2018), complete censuses were conducted to record the presence of black howler monkeys, with 264 forest fragments visited during the period 2005-2012 (for further information, refer to Pozo-Montuy et al. 2008, 2011). Of these, and based on logistical criteria, a subsample of 30 fragments with confirmed presence of black howler monkeys was selected for the present study (Figure 1). Within the period January-December 2006, in each fragment the size and age-sex structure of howler monkeys was recorded, the ecological density (i. e., number of individuals per fragment size, Rodríguez-Toledo et al. 2003) was calculated, and fresh stool samples were collected from 33 males and 32 females of different groups $(n=65)$. Stool samples were collected opportunistically during population surveys and only when individuals could be identified. These samples were preserved in $10 \%$ formaldehyde solution, labeled with the information of origin (e. g., fragment, group, specimen identity), and sent to the Laboratory of Parasitology in the Department of Environmental Sciences at Emory University.

Stool ova and parasite testing. We used the protocol of concentration by flotation and sedimentation $\left(\mathrm{NaNO}_{3}\right.$ solution), as described in Gillespie (2006), to retrieve helminth eggs and cysts of intestinal protozoa excreted in howler monkey stools. This protocol is highly effective to estimate intestinal parasitic infections using non-invasive methods in various species of wild primates (Gillespie and Chapman 2008). Two slides were systematically examined under a light microscope (Leica ${ }^{\circledR}$ DM500) for each parasite concentration technique. This procedure was carried out for each stool sample. No intestinal protozoan cysts were found in these samples. Parasite eggs (i. e., helminths) were examined at $10 \times$ and measured with a micrometer eyepiece $(0.1$ $\mu \mathrm{m})$ at $40 \times$. One drop of Lugol's iodine solution was added to highlight egg structures and facilitate the taxonomic identification. In addition, photographs of representative eggs were taken for use in the identification and classification of taxa (Figure 2). The recovery of eggs was used for estimating the presence, prevalence and richness of parasites as a measure of parasitic infection. Parasite richness was defined as the number of different taxa observed per stool sample, while parasite prevalence was defined as the proportion of stool samples infected with at least one taxon.

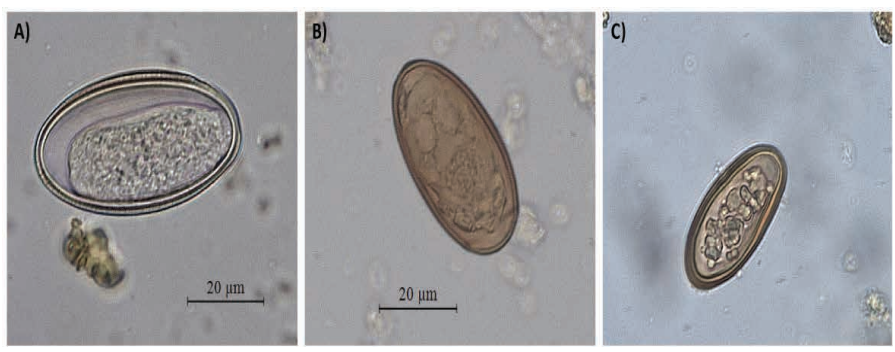

Figure 2. Parasite eggs found in stools of black howler monkeys that inhabit forest fragments in Balancán, Tabasco, Mexico. A) Trypanoxyuris sp., B) Controrchis sp., C) unidentified trematode.
Disturbance Measures. The size of each forest fragment occupied by monkeys and the distance from this fragment to the nearest village were considered as landscape measures of habitat disturbance. Both variables were estimated with orthophotos at scale 1:2,000 using the program ArcView 3.3. These data and estimates have been published in greater detail in Pozo-Montuy et al. (2008, 2011). Fragment size was included considering that larger vegetation patches can accommodate a larger number of individuals, species and ecological interactions, thus mimicking the conditions found in undisturbed habitats (Collins et al. 2017). The distance from each fragment to the closest village was included assuming that fragments in close proximity to human settlements are exposed to greater disturbance (e. g., logging and resource extraction, magnification of the edge effect; Popradit et al. 2015).

Data Analysis. The effects of habitat disturbance on parasitic infection patterns were analyzed using generalized linear models. The effects of habitat disturbance on the presence of parasites were explored by constructing a matrix with values 0 and 1 as response variables, where these figures represented non-infected (absence of parasites) and infected (presence of parasites of any taxon) samples, respectively. In this model, we established a canonical logit link function with binomial distribution (Crawley 2007). Fragment size and distance between a fragment and the nearest town were selected as predictors. Also included was ecological host density in each fragment due to a potential density-dependent effect on the parasitic infection (Nunn and Altizer 2006). Since samples were collected in different time points, these models also included seasonality. This was modeled through the sine and cosine of the day of collection, previously transformed into a circular variable (day within the year $\times 2 \times \pi / 365$ ) (Gillespie et al. 2013). The sex of specimens was also considered as a predictor.

In order to investigate the effects of habitat disturbance on parasite richness, we built another model including the number of parasite taxa in each stool sample as the response variable and the same predictors mentioned above. In this model, we established a canonical log link function and used the Poisson distribution (Crawley 2007). All models were run in the program $\mathrm{R}$ (version 3.2.4.) using the package MASS (Ripley et al. 2017). Taking into account all the predictors, an analysis for the selection of the best model was carried out using the "dredge" function of the package MuMIn (Barton 2017). This produces a series of potential combinations of the predictors previously specified. The best model for both the presence and richness of parasites was chosen according to the Akaike information criterion (Burnham et al. 2001). The significance of the best model to explain the data was evaluated with an analysis of deviance, which compares the goodness of fit of the best model vs. a null model that includes only the intercept. A plot of the significant effects of generalized linear models was drawn with the "effects" package (Fox et al. 2016) in R. Three stool samples belonging to one group were excluded from these 
analyses due to missing ecological information about the fragment. Parasitic prevalence values were calculated in the program Quantitative Parasitology 3.0 (Rózsa et al. 2000).

\section{Results}

This population of black howler monkeys showed a 39.1 $\%$ prevalence of intestinal parasites ( $95 \% \mathrm{Cl}: 27.1$ to 52.1 ). On average, howler monkeys were infected by $0.5 \pm$ SE 0.08 taxa (range: 0 to 3 taxa). The taxa found were Trypanoxyuris sp. (Oxyuridae), Controrchis sp. (Dicrocoeliidae), and an unidentified trematode of the family Dicrocoeliidae (Figure 2). Trypanoxyuris sp. eggs measured $47.9 \mu \mathrm{m} \pm S D 4.0 \times$ $23.8 \mu \mathrm{m} \pm S D$ 1.4; Controrchis sp. eggs measured $43.1 \mu \mathrm{m}$ $\pm S D 3.3 \times 23.5 \mu \mathrm{m} \pm S D 1.4$; and eggs of the unidentified trematode measured $37.7 \mu \mathrm{m} \pm S D 4.1 \times 22.0 \mu \mathrm{m} \pm S D$ 1.0. Controrchis sp. was the most prevalent parasite (31.6\%), whereas the unidentified trematode and Trypanoxyuris sp. showed prevalence rates of $11.7 \%$ and $5.0 \%$, respectively. Table 1 shows the prevalence of each taxon according to host sex and site of collection. The prevalence of intestinal parasites in black howler monkeys approximately doubled in individuals inhabiting fragments located more than 500 $m$ away from the nearest village (Table 2 ). Considering fragment size, we found a similar prevalence of intestinal parasites in howler monkeys living in fragments varying from < 1 ha to 50 ha, but this increased by $43 \%$ in larger fragments (>50-1200 ha) (Table 2).

The model found to best predict the presence of Gl parasites considers the distance between fragments and closest village, as well as fragment size (Table 3 ). The analysis of deviance showed that the residual model including these two predictors significantly differed from the null model $\left(X^{2}=6.4 ;\right.$ d.f. $\left.=2 ; P=0.04\right)$. A generalized linear model indicated that the distance between forest fragments and the closest villages significantly predicted the presence of Gl parasites $(\beta=0.55 \pm S E 0.28, z=2.0, P=0.05)$. Figure 3 shows that the probability of intestinal parasitic infection increases with the distance between a fragment and the closest village. Although fragment size is an element of the best model, this predictor had no significant effect on the

Table 2. Prevalence of gastrointestinal parasites in black howler monkeys (Alouatta pigra) of Balancán, Tabasco, Mexico, in relation to distance between forest fragments and human settlements, and to fragment size.

\begin{tabular}{lrrr}
\multicolumn{1}{c}{ Predictive variables } & $\begin{array}{c}\text { Number of } \\
\text { Fragments }\end{array}$ & Prevalence (\%) & $n^{a}$ \\
\hline $\begin{array}{l}\text { Distance between fragments and the nearest } \\
\text { village }\end{array}$ & 5 & 29.4 & 17 \\
$100-250 \mathrm{~m}$ & 6 & 26.7 & 14 \\
$>250-250 \mathrm{~m}$ & 8 & 50.0 & 12 \\
$>500-1,000 \mathrm{~m}$ & 10 & 56.3 & 19 \\
$>1,000 \mathrm{~m}$ & & & \\
Range of fragment sizes & 16 & 37.9 & 32 \\
$0.01-10$ ha & 9 & 36.4 & 22 \\
$>10-50$ ha & 5 & 55.6 & 11 \\
$>50-1200$ ha & & & \\
\hline
\end{tabular}

${ }^{a}$ number of stool samples collected
Table 1. Prevalence of three taxa of gastrointestinal parasites associated with the sex of black howler monkeys (Alouatta pigra) inhabiting forest fragments in Balancán Tabasco, Mexico.

\begin{tabular}{|c|c|c|c|c|c|c|c|c|c|}
\hline \multirow[b]{2}{*}{ Fragment } & \multirow[b]{2}{*}{$\begin{array}{l}\text { Size } \\
\text { (ha) }\end{array}$} & \multirow[b]{2}{*}{$\begin{array}{c}\text { Distance } \\
(\mathrm{m})\end{array}$} & \multicolumn{2}{|c|}{$\begin{array}{c}\text { Trypanoxyuris } \\
\text { sp. }\end{array}$} & \multicolumn{2}{|c|}{ Controrchis sp. } & \multicolumn{2}{|c|}{$\begin{array}{l}\text { Unidentified } \\
\text { trematode }\end{array}$} & \multirow[b]{2}{*}{$n^{a}$} \\
\hline & & & Male & Female & Male & Female & Male & Female & \\
\hline 1 & 0.01 & 250 & 0 & 0 & 0 & 20 & 0 & 0 & 5 \\
\hline 2 & 0.01 & 2,500 & 0 & 0 & 0 & 0 & 0 & 0 & 2 \\
\hline 3 & 0.2 & 300 & 0 & 0 & 0 & 0 & 0 & 0 & 2 \\
\hline 4 & 0.8 & NA & 0 & 0 & 0 & 0 & 0 & 0 & 3 \\
\hline 5 & 1.4 & 500 & 0 & 0 & 0 & 0 & 0 & 0 & 1 \\
\hline 6 & 1.5 & 950 & 0 & 0 & 100 & 0 & 0 & 0 & 1 \\
\hline 7 & 1.9 & 600 & 0 & 0 & 50.0 & 0 & 0 & 0 & 2 \\
\hline 8 & 2.1 & 870 & 0 & 0 & 0 & 100 & 0 & 0 & 1 \\
\hline 9 & 2.5 & 1,580 & 0 & 0 & 0 & 100 & 0 & 100 & 1 \\
\hline 10 & 2.8 & 120 & 0 & 33.3 & 0 & 33.3 & 0 & 0 & 3 \\
\hline 11 & 3.8 & 1,019 & 0 & 0 & 100 & 0 & 0 & 0 & 1 \\
\hline 12 & 4.1 & 200 & 0 & 0 & 0 & 0 & 0 & 0 & 1 \\
\hline 13 & 4.5 & 670 & 0 & 0 & 0 & 0 & 100 & 0 & 1 \\
\hline 14 & 4.7 & 1,214 & 0 & 0 & 0 & 0 & 0 & 0 & 1 \\
\hline 15 & 4.9 & 2,400 & 0 & 0 & 100 & 0 & 0 & 0 & 2 \\
\hline 16 & 6.7 & 400 & 0 & 0 & 20.0 & 0 & 0 & 0 & 5 \\
\hline 17 & 11.2 & 2,500 & 50.0 & 0 & 50.0 & 0 & 0 & 0 & 2 \\
\hline 18 & 14.5 & 708 & 0 & 0 & 0 & 50.0 & 0 & 0 & 2 \\
\hline 19 & 17.0 & 780 & 0 & 0 & 0 & 0 & 0 & 0 & 1 \\
\hline 20 & 21.9 & 2,408 & 0 & 0 & 0 & 0 & 0 & 50.0 & 2 \\
\hline 21 & 24.4 & 100 & 0 & 0 & 14.2 & 28.5 & 14.2 & 14.2 & 7 \\
\hline 22 & 25.0 & 400 & 0 & 0 & 0 & 0 & 0 & 0 & 1 \\
\hline 23 & 26.6 & 1,381 & 0 & 0 & 33.3 & 33.3 & 33.3 & 0 & 3 \\
\hline 24 & 30.0 & 400 & 0 & 0 & 0 & 0 & 0 & 0 & 1 \\
\hline 25 & 39.0 & 560 & 0 & 0 & 0 & 0 & 0 & 0 & 3 \\
\hline 26 & 76.9 & 250 & 0 & 0 & 0 & 0 & 0 & 0 & 1 \\
\hline 27 & 166.0 & 1,235 & 0 & 0 & 0 & 0 & 0 & 100 & 1 \\
\hline 28 & 200.0 & 1,200 & 0 & 0 & 0 & 0 & 0 & 0 & 4 \\
\hline 29 & 288.5 & 950 & 0 & 0 & 0 & 0 & 0 & 0 & 1 \\
\hline 30 & $1,200.0$ & 455 & 0 & 0.25 & 0 & 50 & 0 & 0 & 4 \\
\hline
\end{tabular}

${ }^{a}$ number of stool samples collected

NA: Information not available

presence of parasites $(\beta=0.48 \pm S E 0.30, z=1.6, P=0.11)$. Other predictors considered in this analysis had no significant effects on the presence of intestinal parasites.

Ecological density was the best predictor of parasite richness in the model selection analysis; however, this model had no significant effects (analysis of deviance: $x^{2}=$ $2.4 ; \mathrm{d}$. f. $=1 ; P=0.12$ ). The other predictors considered also showed no significant effects on parasite richness.

\section{Discussion}

In the present investigation, we conducted an ova and parasite stool study to assess the effects tropical forest disturbance on parasitic infection patterns of in black howler monkeys threatened with extinction. We found that as the extent of disturbance increases - estimated through the proximity of human settlements to forest fragments - the presence of parasites in this population of primates 


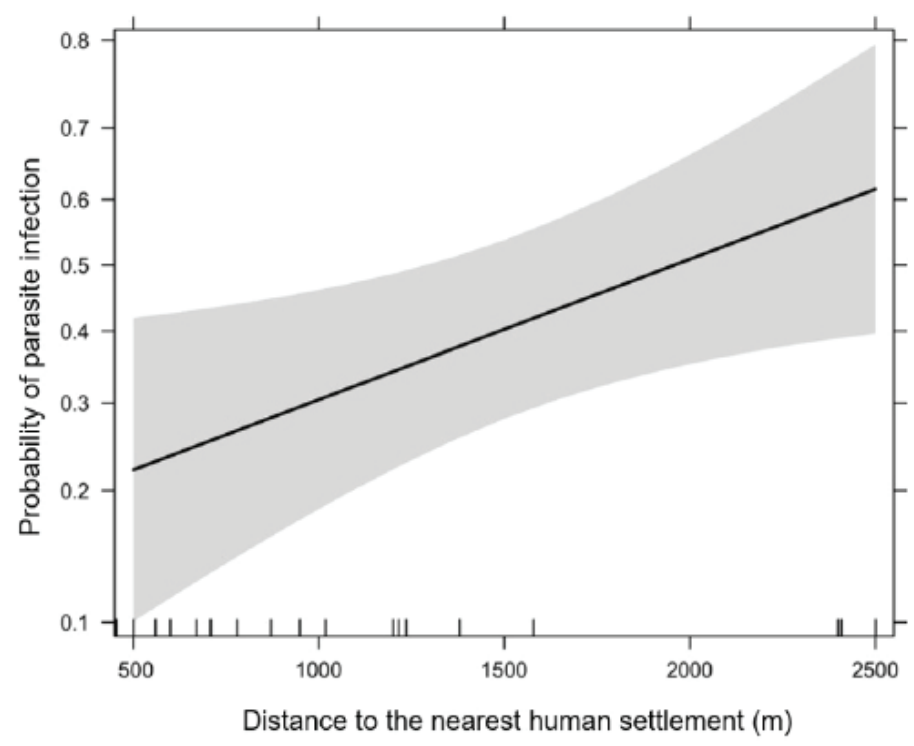

Figure 3. Relationship between distance $(\mathrm{m})$ from forest fragments to the nearest village and likelihood of intestinal parasitic infection in black howler monkeys living in Balancán, Tabasco, Mexico. The shaded area represents $95 \%$ confidence intervals.

decreases. Also, a higher prevalence of parasites was observed in monkeys inhabiting fragments further away from villages. These findings suggest that infection rates, and probably also the transmission processes of parasites infecting black howler monkeys, are disrupted as anthropogenic activities are intensified in the proximity of fragments.

In this population of primates, we also found that parasite richness ( $n=3$ taxa) is low relative to the one reported for howler monkey populations living in undisturbed environments (Table 4). In these populations, individual monkeys carry a higher number of parasite species, ranging from 4 to 9 taxa. In contrast to our results, a study carried out in forest fragments in the southern region of the municipality of Balancán, Tabasco, reported 13 taxa of parasites, 11 of which showed a prevalence of 2 to $10 \%$ (AlvaradoVillalobos 2015). Despite the higher number of taxa found at that site, the low prevalence indicates that infections involving multiple taxa are rare in the area. It is possible that the variability observed in the recovery of parasite species partly resulted from the different parasitological techniques used in other investigations (Alvarado-Villalobos et al. 2017); however, our results are consistent with the richness reported for other monkey populations inhabiting fragmented areas (Table 4).

The low probability of occurrence of parasites in the proximity to human settlements and the low richness recorded may be associated to the high degree of ecosystem disturbance and changes of land use in the municipality of Balancán, Tabasco. In particular, this area is recurrently affected by fires associated to pasture burning and practices such slash-and-burn in cropland areas surrounding forest fragments (Manjarrez Muñoz et al. 2007). These activities alter the microclimate of the forest floor, considerably reducing soil moisture and increasing desiccation (Laurance 2004). These changes have been reported to reduce the survival of infectious stages of parasites (Bloemers et al.
1997). The low probability of occurrence of parasites in this population of howler monkeys likely reflects the synergy resulting from the reduction in the parasite-host encounter rates (Bordes et al. 2015) and the low resilience of parasites to survive in a highly disturbed ecosystem.

The parasites reported in this research are considered to be specialists, as they have been found specifically in a monophyletic group of Neotropical arboreal primates (family Atelidae; Solórzano-Garcia and Pérez-Ponce de León 2017). It has been proposed that host-specialized parasites tend to be more susceptible to extinction compared with generalist parasites, which manage to persist in the environment by parasitizing a greater variety of hosts belonging to different evolutionary lineages (Farrell et al. 2015). In this context, the decline of howler monkey populations may also lead to the loss of parasites that infect only this endemic primate species. For instance, Solórzano-García et al. (2016) have recently described the species Trypanoxyuris pigrae, a nematode that parasitizes specifically A. pigra and that may be threatened of extinction along with its host.

On the other hand, the high discontinuity of the canopy in some forest fragments in this area forces howler monkeys to descend to the ground to move across treeslocated either within fragments or in the matrix of fragmented landscapes (Pozo-Montuy and Serio-Silva 2007). It has been proposed that this shift in behavior increases the likelihood of contact between primates and infectious stages of parasites deposited in soil and whose primary hosts are humans or livestock (Rwego et al. 2008; Zommers et al. 2013). However, in this study we found none of the parasite species reported in humans or domestic animals. In a recent research, Helenbrook et al. (2015) explored the possibility of cross-transmission of the parasite Blastocystis sp. between mantled howler monkeys ( $A$. palliata aequatoria-

Table 3. Results of the analysis for the selection of models that predict the presence of gastrointestinal parasites in black howler monkeys (Alouatta pigra) in Balancán, Tabasco, Mexico.

\begin{tabular}{lccccc}
\hline \multicolumn{1}{c}{ Model } & D. F. & $\begin{array}{c}\text { Log- } \\
\text { likelihood }\end{array}$ & AICc & AAICC & Weight \\
\hline Distance + Size & 3 & -37.178 & 80.8 & 0.00 & 0.058 \\
Distance + Density + Sex & 4 & -36.206 & 81.1 & 0.36 & 0.048 \\
Distance + Size + Density & 4 & -36.354 & 81.4 & 0.65 & 0.042 \\
Distance & 2 & -38.679 & 81.6 & 0.78 & 0.039 \\
Distance + Density & 3 & -37.592 & 81.6 & 0.83 & 0.038 \\
Distance + Sex & 3 & -37.651 & 81.7 & 0.95 & 0.036 \\
Distance + Size + Sex & 4 & -36.662 & 82.1 & 1.27 & 0.031 \\
Distance + Size + Density + Sex & 5 & -35.547 & 82.2 & 1.42 & 0.028 \\
Distance + Density + Seasonality (sine) + Sex & 5 & -35.564 & 82.2 & 1.45 & 0.028 \\
Distance + Seasonality (cosine) & 3 & -37.971 & 82.4 & 1.59 & 0.026 \\
Distance + Density + Seasonality (sine) & 4 & -36.954 & 82.6 & 1.85 & 0.023 \\
Density + Seasonality (sine) & 3 & -38.103 & 82.6 & 1.85 & 0.023 \\
Distance + Size + Seasonality (sine) & 4 & -36.956 & 82.6 & 1.86 & 0.023 \\
Size & 2 & -39.219 & 82.6 & 1.87 & 0.023 \\
Distance + Seasonality (sine) & 3 & -38.139 & 82.7 & 1.92 & 0.022 \\
Seasonality (sine) & 2 & -39.289 & 82.8 & 2.00 & 0.021 \\
\hline
\end{tabular}

Models are listed from lowest to highest value of the Akaike Information criterion (AICc) 
Table 4. Richness and prevalence of gastrointestinal parasites in different populations of black howler monkeys (Alouatta pigra)

\begin{tabular}{|c|c|c|c|c|c|c|c|}
\hline Habitat & Site ${ }^{a}$ & $\begin{array}{l}\text { Number of } \\
\text { individuals }\end{array}$ & $\begin{array}{c}\text { Number of } \\
\text { stool samples }\end{array}$ & Richness & $\begin{array}{c}\text { Range of } \\
\text { prevalence }\end{array}$ & $\operatorname{Taxa}^{\mathrm{b}}$ & Reference \\
\hline \multirow[t]{5}{*}{ Undisturbed } & LAR, CBS & 167 & 167 & 6 & $2.0-80.8$ & $1,12,20,30,31,32$ & Eckert et al. 2006 \\
\hline & CBS, CBWS, PA, CK & 50 & 283 & 4 & $27.0-81.0$ & $6,12,18,28$ & Vitazkova and Wade 2006 \\
\hline & MA & 15 & 151 & 8 & $25.0-35.0$ & $3,12,13,17,21,24,25,33$ & Stoner and González Di Pierro 2006 \\
\hline & CK, ES, PA, MA & 137 & 137 & 4 & $2.5-17.0$ & $6,23,27,37$ & Trejo-Macías et al. 2007 \\
\hline & $\mathrm{PT}, \mathrm{TG}$ & 8 & 8 & 9 & $12.5-50.0$ & $2,7,8,9,11,13,15,16,18$ & Bonilla Moheno 2002 \\
\hline \multirow[t]{8}{*}{ Fragmented } & $\mathrm{MR}$ & 17 & 221 & 5 & $11.1-88.9$ & $1,5,26,27,36$ & Behie et al. 2014 \\
\hline & MC & 22 & 22 & 3 & $7.7-50.0$ & $23,24,35$ & Trejo-Macías et al. 2007 \\
\hline & PC & 43 & 218 & 3 & $9.1-73.0$ & $6,9,27$ & Alvarado-Villalobos 2010 \\
\hline & ES & 15 & 258 & 5 & $0.7-49.0$ & $6,13,22,27,34$ & Martínez-Mota et al. 2017 \\
\hline & $\mathrm{PL}, \mathrm{PH}$ & 3 & 3 & 6 & $33.3-100$ & $2,7,11,13,16,18$ & Bonilla Moheno 2002 \\
\hline & SB & 41 & 492 & 13 & $2.4-83.0$ & $1,3,4,5,9,10,12,14,17,19,24,27,30$ & Alvarado-Villalobos 2015 \\
\hline & $\mathrm{T}, \mathrm{C}$ & 10 & 46 & 4 & $2.2-23.9$ & $24,27,28,29$ & $\begin{array}{l}\text { Solórzano-García and Pérez-Ponce } \\
\text { de León } 2017\end{array}$ \\
\hline & MB & 65 & 65 & 3 & $5.0-31.6$ & $5,27,34$ & This study \\
\hline
\end{tabular}

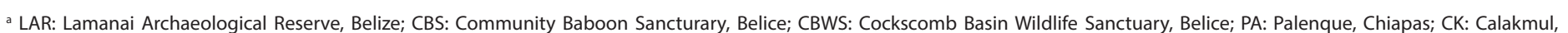

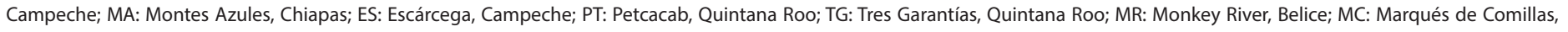

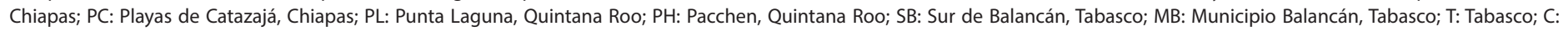
Chiapas.

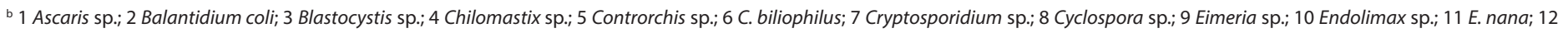

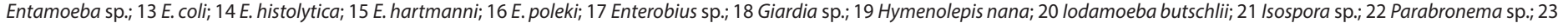

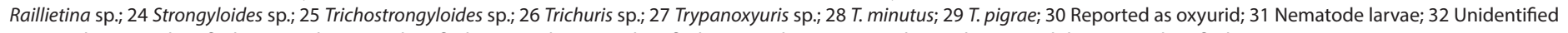
trematode; 33 Unidentified trematode; 34 Unidentified trematode; 35 Unidentified trematode; 36 Reported as Trichostrongylidae; 37 Unidentified parasite.

lis) and humans coexisting in close proximity, but found no evidence of transmission between species. Pedersen and Davies (2009) suggest that the transmission of parasites between host species is more likely to occur in phylogenetically closer taxa. As the evolutionary relationship between monkeys and either humans or domestic animals is distant (Perelman et al. 2011), this could explain the absence of parasites shared between monkeys and humans/livestock despite the frequent contact of this population of primates with human settlements and farming activities in the area. Further stool ova and parasite studies using molecular techniques may provide compelling information concerning the parasite transmission processes between black howler monkeys and other species.

Our results contrast with those obtained in other studies that have investigated the parasite ecology of wild primates. For example, in colobus (Procolobus rufomitratus) and macaque (Macaca silenus) monkeys, it has been found that individuals who live in highly disturbed forests show higher rates of Gl parasitism (Gillespie and Chapman 2008; Hussain et al. 2013). These shifts in susceptibility to parasitic infections are seemingly related to nutritional stress (Chapman et al. 2015). However, recent studies on black howler monkeys show that these primates are able to prevent nutritional stress by consuming food items of different nutritional quality and energy content, supplementing the diet with food gathered across the landscape matrix (PozoMontuy et al. 2013; Martinez-Mota et al. 2016). An alternative hypothesis is that the intake of secondary metabolites from plants through the diet might reduce parasitic infections (Forbey et al. 2009). Tinto (H. campechianum) is a plant frequently consumed by howler monkeys in the study area, which contains secondary compounds such as phenols, flavonoids and gallotannins (Kandil et al. 1999). These compounds may negatively affect the viability of parasites, as previously reported in experimental studies (Athanasiadou and Kyriazakis 2004). This hypothesis deserves further investigation. The trend observed in our study indicates that changes in host-parasite dynamics in relation to habitat disturbance are specific for each biological system (Salkeld et al. 2013).

Despite the fact that parasitic infections are often associated with a negative or poor health condition in animals, parasites are members of healthy ecosystems, functioning as a link in food webs, and making a significant contribution to global biodiversity (Marcogliese 2005; Shea et al. 2012; Sukhdeo 2012). Our study suggests that habitat disruption affects not only populations of appealing species, but also the persistence of parasite communities, which is reflected on the patterns of gastrointestinal parasite infections in wild primates that depend strictly on tropical forests.

\section{Acknowledgments}

We are grateful to the Department of Environmental Sciences at Emory University for the support to carry out the parasitological testing, and to the communities of the municipality of Balancán, in particular P. Magaña, J. M. Garcia González and D. Tejero Geronimo for their assistance and access to perform the field work. We are grateful to SEMARNAT for the license to conduct this study (SEMARNAT/SGPA/DGVS/02465/06). G. P. M., and Y. M. B. S. thank the National Council for Science and Technology for the scholarships awarded to undertake 
the master's and doctoral programs. María Elena SánchezSalazar translated the manuscript into English.

\section{Literature cited}

Altizer, S., C. L. Nunn, y P. Lindenfors. 2007. Do threatened hosts have fewer parasites? A comparative study in primates. Journal of Animal Ecology 76:304-314.

Alvarado-Villalobos, M. A. 2015. Fluctuación de la comunidad de parásitos gastrointestinales de Alouatta pigra en diferentes condiciones de hábitat. Tesis de Maestría. Instituto de Ecología, A. C. Xalapa, México.

Alvarado-Villalobos, M. A., G. Cringoli, M. P. Maurelli, A. Cambou, L. Rinaldi, A. Barbachano-Guerrero, R. Guevara, C. A. Chapman, and J. C. SerIO-SILva. 2017. Flotation techniques (FLOTAC and miniFLOTAC) for detecting gastrointestinal parasites in howler monkeys. Parasites and Vectors 10:586.

AtHANASIADOU, S., AND I. KYRIAZAKIS. 2004. Plant secondary metabolites: antiparasitic effects and their role in ruminant production systems. Proceedings of the Nutrition Society 63:631-639.

BARTON, K. 2017. Multi-model inference. R package version 1.40.4. Bloemers, G. F., M. Hodda, P. J. D. Lambshead, J. H. Lawton, and F. R. WANLESS. 1997. The effects of forest disturbance on diversity of tropical soil nematodes. Oecologia 111:575-582.

Bordes, F., S. Morand, S. Pllosof, J. Claude, B. R. Krasnov, J. F. Cosson, Y. Chaval, A. Ribas, K. ChaisiRl, K. Blasdell, V. Herbreteau, S. Dupuy, AND A. TrAN. 2015. Habitat fragmentation alters the properties of a host-parasite network: rodents and their helminths in South-East Asia. Journal of Animal Ecology 84:1253-1263.

Burnham, K. P., D. R. Anderson, and K. P. Huyvaert. 2011. AIC model selection and multimodel inference in behavioral ecology: some background, observations, and comparisons. Behavioral Ecology and Sociobiology 65:23-35.

Bush, S. E., M. ReED, and S. Maher. 2013. Impact of forest size on parasite biodiversity: implications for conservation of hosts and parasites. Biodiversity and Conservation 22:1391-1404.

Chapman, C. A., V. A. M. Schoof, T. R. Bonnell, J. F. Gogarten, And S. CALMÉ. 2015. Competing pressures on populations: longterm dynamics of food availability, food quality, disease, stress and animal abundance. Philosophical Transactions of the Royal Society of London B 370:20140112.

Coluins, C. D., C. Banks-Leite, L. A. Brudvig, B. L. Foster, W. M. Cook, E. I. Damschen, A. Andrade, M. Austin, J. L. Camargo, D. A. Driscoll, R. D. Holdt, W. F. Laurance, A. O. Nicholls, and J. L. Orrock. 2017. Fragmentation affects plant community composition over time. Ecography 40:119-130.

Colwell, R. K., R. R. Dunn, AND N. C. HarRIs. 2012. Coextinction and persistence of dependent species in a changing world. Annual Review of Ecology, Evolution, and Systematics 43:183-203.

CONAGUA. 2017. Comisión Nacional del Agua. Disponible en http://smn.cna.gob.mx/es/climatologia/informacionclimatologica. Última consulta el 12 de junio 2017.

Crawley, M. J. 2007. The R book. John Wiley \& Sons, Ltd. United Kingdom.

Donaldson, M. R., N. J. Burnett, D. C. Braun, C. D. Suski, S. G. Hinch, S. J. COOKE, AND J. T. KERR. 2016. Taxonomic bias and international biodiversity conservation research. FACETS 1:105-113.
Estrada, A. 2015. Conservation of Alouatta: social and economic drivers of habitat loss, information vacuum, and mitigating population declines. Pp. 383-409, in Howler Monkeys: behavior, ecology, and conservation (Kowalewski, M. M, P. A. Garber, L. Cortés-Ortiz, B. Urbani, and D. Youlatos, eds.). Springer. New York, U. S. A.

Estrada, A., P. A. Garber, A. B. Rylands, C. Roos, E. FernandezDuque, A. Di Fiore, K. A. Nekaris, V. Nijman, E. W. Heymann, J. E. Lambert, F. Rovero, C. Barelli, J. M. Setchell, T. R. Gillesple, R. A. Mittermeier, L. Verde Arregoitia, M. de Guinea, S. Gouveia, R. Dobrovolski, S. Shanee, N. Shanee, S. A. Boyle, A. Fuentes, K. C. Mackinnon, K. R. Amato, A. L. S. Meyer, S. Wich, R. W. Sussman, R. PAN, I. KonE, AND B. LI. 2017. Impending extinction crisis of the world's primates: why primates matter. Science Advances 3:e1600946.

Farrell, M. J., P. R. Stephens, L. BerRang-Ford, J. L. Gittleman, and T. J. Davies. 2015. The path to host extinction can lead to loss of generalist parasites. Journal of Animal Ecology 84:978-984.

Forbey, J. S., A. L. Harvey, M. A. Huffman, F. D. Provenza, R. Sullivan, AND D. TASDEMIR. 2009. Exploitation of secondary metabolites by animals: a response to homeostatic challenges. Integrative and Comparative Biology 49:314-328.

Fox, J., S. Weisberg, M. Friendly, J. Hong, R. Andersen, D. Firth, and S. TAYLOR. 2016. Effect displays for linear, generalized linear, and other models. R package version 4.0-0.

GILLESPIE, T. R. 2006. Noninvasive assessment of gastrointestinal parasite infections in free-ranging primates. International Journal of Primatology 27:1129-1143.

Gillespie, T. R., and C. A. Chapman. 2008. Forest fragmentation, the decline of an endangered primate, and changes in hostparasite interactions relative to an unfragmented forest. American Journal of Primatology 70:222-230.

Gillespie, T. R., C. Barelli, And M. Heistermann. 2013. Effects of social status and stress on patterns of gastrointestinal parasitism in wild white-handed gibbons (Hylobates lar). American Journal of Physical Anthropology 150:602-608.

Haddad, N. M., L. A. Brudvig, J. Clobert, K. F. Davies, A. Gonzalez, R. D. Holdt, T. E. Lovejoy, J. O. Sexton, M. P. Austin, C. D. Collins, W. M. Cook, E. I. Damschen, R. M. Ewers, B. L. Foster, C. N. Jenkins, A. J. King, W. F. Laurance, D. J. Levey, C. R. Margules, B. A. Melbourne, A. O. Nocholls, J. L. OrRock, D. Song, And J. R. Townshend. 2015. Habitat fragmentation and its lasting impact on Earth's ecosystems. Science Advances 20:e1500052.

Helenbrook, W. D., W. M. Shields, and C. M. Whipps. 2015. Characterization of Blastocystis species infection in humans and mantled howler monkeys, Alouatta palliata aequatorialis, living in close proximity to one another. Parasitology Research 114:2517-2525.

Hosonuma, N., M. Herold, V. De Sy, R. S. De Fries, M. Brockhaus, L. VerChOt, A. Angelsen, AND E. Romijn. 2012. An assessment of deforestation and forest degradation drivers in developing countries. Environmental Research Letters 7:044009.

Hussain, S., M. S. Ram, A. Kumar, S. Shival, and G. Umapathy. 2013. Human presence increases parasitic load in endangered liontailed macaques (Macaca silenus) in its fragmented rainforest habitats in southern India. PLOS ONE 8:e63685. 
Isaac-Márquez, R., B. de Jong, A. Eastmond, S. Ochoa-Gaona, S. Hernández, And J. L. Sandoval. 2008. Programas gubernamentales y respuestas campesinas en el uso del suelo: el caso de la zona oriente de Tabasco, México. Región y Sociedad 20:97-129.

IUCN. 2017. The IUCN Red List of Threatened Species. Disponible en http://www.iucnredlist.org/. Última consulta el 12 de julio 2017.

Johnson, C. N., A. Balmford, B. W. Brook, J. C. Buettel, M. Galetti, L. Guangchun, And J. M. Wilmshurst. 2017. Biodiversity losses and conservation responses in the Anthropocence. Science 356:270-275.

Kandil, F. E., H. N. Michael, M. S. Ishak, and T. J. Mabry. 1999. Phenolics and flavonoids from Haematoxylon campechianum. Phytochemistry 51:133-134.

LAFFERTY, K. D. 2012. Biodiversity loss decrease parasite diversity: theory and patterns. Philosophical Transactions of the Royal Society of London B 367:2814-2827.

Lafferty, K. D., AND A. M. KurIs. 2005. Parasitism and environmental disturbances. Pp. 113-123, in Parasitism and Ecosystems (Thomas, F., F. Renaud, and J. F. Guégan, eds.). Oxford University Press. Oxford, United Kingdom.

LAURANCE, W. F. 2004. Forest-climate interactions in fragmented tropical landscapes. Philosophical Transactions of the Royal Society of London B 359:345-352.

López-MendozA, R. 1980. Tipos de vegetación y su distribución en el estado de Tabasco y norte de Chiapas. Universidad Autónoma de Chapingo, Centro Regional Tropical Puyacatengo, Dirección de Difusión Cultural. Ciudad de México, México.

Manjarrez Muñoz, B., S. Hernández Daumás, B. de Jong, J. Nahed Toral, O. O. D. Vallejo, and E. B. Salvatierra Zaba. 2007. Configuración territorial y perspectivas de ordenamiento de la ganadería bovina en los municipios de Balancán y Tenosique, Tabasco. Investigaciones Geográficas, Boletín del Instituto de Geografía, Universidad Nacional Autónoma de México 64:90-115.

Marcogliese, D. J. 2005. Parasites of the superorganism: are they indicators of ecosystem health? International Journal for Parasitology 35:705-716.

Martínez-Mota, R. 2015. The effects of habitat disturbance, host traits, and host physiology on patterns of gastrointestinal parasite infection in black howler monkeys (Alouatta pigra). Tesis doctoral. Department of Anthropology, University of Illinois at Urbana-Champaign, Urbana, U. S. A.

Martínez-Mota, R., N. Righini, and R. Palme. 2016. Fluctuations in daily energy intake do not cause nutritional stress in a Neotropical primate living in a seasonal forest. Oecologia 182:973-984.

MoRRIS, R. J. 2010. Anthropogenic impacts on tropical forest biodiversity: a network structure and ecosystem functioning perspective. Philosophical Transactions of the Royal Society of London B 365:3709-3718.

Nunn, C.L., And S. Altizer. 2006. Infectious diseases in primates: behavior, ecology and evolution. Oxford University Press. Oxford, United Kingdom.

Nunn, C. L., AND T. R. Gillespie. 2016. Infectious disease and primate conservation. Pp. 157-173, in An Introduction to Primate Conservation (Wich, S. E. , and A. J. Marshall, eds.). Oxford University Press. Oxford, United Kingdom.
Pedersen, A. B., And T. J. Davies. 2009. Cross-species pathogen transmission and disease emergence in primates. Ecohealth 6:496-508.

Perelman, P., W. E. Johnson, C. Roos, H. N. Seuánez, J. E. Horvath, M. A. M. Moreira, B. Kessing, J. Pontius, M. Roelke, Y. Rumpler, M. P. C. Schneider, A. Silva, S. J. O’Brien, and J. Pecon-Slattery. 2011. A molecular phylogeny of living primates. PLOS Genetics 7:e1001342.

Popradit, A., T. Srisatit, S. Kiratiprayoon, J. Yoshimura, A. Ishida, M. Shiyomi, T. Murayama, P. Chantaranothal, S. Outtaranakorn, and I. Phromma. 2015. Anthropogenic effects on a tropical forest according to the distance from human settlements. Scientific Reports 5:14689.

Pozo-Montuy, G., and J. C. Serio-Silva. 2007. Movement and resource use by a group of Alouatta pigra in a forest fragment in Balancán, México. Primates 48:102-107.

Pozo-Montuy, G., J. C. Serio-Silva, Y. M. Bonilla-Sánchez, N. Bynum, AND R. Landgrave. 2008. Current status of the habitat and population of the black howler monkey (Alouatta pigra) in Balancán, Tabasco, Mexico. American Journal of Primatology 70:1169-1176.

Pozo-Montuy, G., J. C. Serio-Silva, and Y. M. Bonilla-Sánchez. 2011. Influence of the landscape matrix on the abundance of arboreal primates in fragmented landscapes. Primates 52:139-147.

Pozo-Montuy, G., J. C. Serio-Silva, C. A. Chapman, and Y. M. BonillaSÁnCHEZ. 2013. Resource use in a landscape matrix by an arboreal primate: evidence of supplementation in black howlers (Alouatta pigra). International Journal of Primatology 34:714-731.

Püttker, T., Y. Meyer-Lucht, AND S. Sommer. 2008. Effects of fragmentation on parasite burden (nematodes) of generalist and specialist small mammal species in secondary forest fragments of the coastal Atlantic Forest, Brazil. Ecological Research 23:207-215.

Ribeiro, E. M. S., V. Arroyo-Rodríguez, B. A. Santos, M. Tabarelli, and I. R. LeAL. 2015. Chronic anthropogenic disturbance drives the biological impoverishment of the Brazilian caatinga vegetation. Journal of Applied Ecology 52:611-620.

Ripley, B., B. Venables, D. M. Bates, K. Hornik, A. Gebhardt, and D. FIRTH. 2017. Support functions and datasets for Venables and Ripley's MASS. R package version 7.3-47.

Rodríguez-Toledo, E. M., S. Mandujano, and F. García-Orduña. 2003. Relationships between forest fragments and howler monkeys (Alouatta palliata mexicana) in Southern Veracruz, Mexico. Pp. 79-97, in Primates in Fragments: Ecology and Conservation (Marsh, L. K., ed.). Kluwer Academic/Plenum Publishers. New York, U. S. A.

RózsA, L., J. REICZIGEL, AND G. MAjOROS. 2000. Quantifying parasites in samples of hosts. Journal of Parasitology 86:228-232.

Rwego, I. B., G. Isabirye-Basuta, T. R. Gillespie, And T. L. Goldberg. 2008. Gastrointestinal bacterial transmission among humans, mountain gorillas, and livestock in Bwindi Impenetrable National Park, Uganda. Conservation Biology 22:1600-1607. RYKIEL, E. J. 1985. Towards a definition of ecological disturbance. Australian Journal of Ecology 10:361-365. 
Salkeld, D. J., K. A. Padgett, And J. H. Jones. 2013. A meta-analysis suggesting that the relationship between biodiversity and risk of zoonotic pathogen transmission is idiosyncratic. Ecology Letters 16:679-686.

Shea, J., G. J. Kersten, C. M. Puccia, A. T. Stanton, S. N. Stiso, E. S. Helgeson, AND E. J. BACK. 2012. The use of parasites as indicators of ecosystem health as compared to insects in freshwater lakes of the Inland Northwest. Ecological Indicators 13:184-188.

Solórzano-García, B., and G. Pérez-Ponce de León. 2017. Helminth parasites of howler and spider monkeys of Mexico: insights into molecular diagnostic methods and their importance for zoonotic diseases and host conservation. International Journal for Parasitology 6:76-84.

Solórzano-García, B., S. A. Nadler, and G. Pérez-Ponce de León. 2016. Pinworm diversity in free-ranging howler monkeys (Alouatta spp.) in Mexico: morphological and molecular evidence for two new Trypanoxyuris species (Nematoda: Oxyuridae). Parasitology International 65:401-411.

Strona, G. 2015. Past, present and future of host-parasite coextinctions. International Journal for Parasitology, Parasites and Wildlife 4:431-441.

SUKHDEO, M. V. K. 2012. Where are the parasites in food webs? Parasite and Vectors 5:239.

Tobón, W., T. Urquiza-Haas, G. Ramos-Fernández, E. Calixto Pérez, J. Alarcón, M. Kolb, and P. Koleff. 2012. Prioridades para la conservación de los primates en México. Comisión Nacional para el Conocimiento y Uso de la Biodiversidad - Asociación Mexicana de Primatología, A. C. - Comisión Nacional de Áreas Naturales Protegidas, México. Disponible en: http://www. biodiversidad.gob.mx/pais/pdf/prioridades primates.pdf

Trejo-Macías, G., and A. Estrada. 2012. Risk factors connected to gastrointestinal parasites in mantled Alouatta palliata mexicana and black howler monkeys Alouatta pigra living in continuous and in fragmented rainforests in Mexico. Current Zoology 58:375-383.

Zommers, Z., D. W. Macdonald, P. J. Johnson, And T. R. Gillespie. 2013. Impact of human activity on chimpanzee ground use and parasitism (Pan troglodytes). Conservation Letters 6:264-273.

Associated editor: Sergio Solari

Submitted: November 7, 2017; Reviewed: January 10, 2018;

Accepted: February 5, 2018; Published on line: May 28, 2018. 
